\title{
Parabanic acid is the singlet oxygen specific oxidation product of uric acid
}

\author{
Sayaka lida, Yuki Ohkubo, Yorihiro Yamamoto and Akio Fujisawa* \\ School of Bioscience and Biotechnology, Tokyo University of Technology, 1404-1 Katakura-cho, Hachioji, Tokyo 192-0982, Japan
}

(Received 8 March, 2017; Accepted 16 May, 2017; Published online 5 September, 2017)

\begin{abstract}
Uric acid quenches singlet oxygen physically or reacts with it, but the oxidation product has not been previously characterized. The present study determined that the product is parabanic acid, which was confirmed by LC/TOFMS analysis. Parabanic acid was stable at acidic $\mathrm{pH}(<5.0)$, but hydrolyzed to oxaluric acid at neutral or alkaline $\mathrm{pH}$. The total yields of parabanic acid and oxaluric acid based on consumed uric acid were $\sim 100 \%$ in clean singlet oxygen production systems such as UVA irradiation of Rose Bengal and thermal decomposition of 3-(1,4-dihydro-1,4-epidioxy-4-methyl-1naphthyl)propionic acid. However, the ratio of the amount of uric acid consumed to the total amount of singlet oxygen generated was less than $1 / 180$, indicating that most of the singlet oxygen was physically quenched. The total yields of parabanic acid and oxaluric acid were high in the uric acid oxidation systems with hydrogen peroxide plus hypochlorite or peroxynitrite. They became less than a few percent in peroxyl radical-, hypochloriteor peroxynitrite-induced oxidation of uric acid. These results suggest that parabanic acid could be an in vivo probe of singlet oxygen formation because of the wide distribution of uric acid in human tissues and extracellular spaces. In fact, sunlight exposure significantly increased human skin levels of parabanic acid.
\end{abstract}

Key Words: singlet oxygen, uric acid, parabanic acid, oxaluric acid, sunlight exposure

$\mathrm{O}$ xidative stress induces lipid peroxidation, ${ }^{(1)}$ DNA damage, ${ }^{(2)}$ and protein carbonylation, ${ }^{(3)}$ which can lead to diseases such as cancer, ${ }^{(4)}$ diabetes, ${ }^{(5)}$ Alzheimer's disease, ${ }^{(6)}$ and ischemia reperfusion injury. ${ }^{(7,8)}$ Since initial oxidative stress is caused by various reactive oxygen species (ROS), the importance of identifying ROS in vivo is of interest in clinical investigations.

Identifying ROS in vivo can be done by monitoring an oxidation product as a marker. The oxidized substrate must show high reactivity toward different ROS and yield a specific oxidation product from an individual ROS. Uric acid (UA, Fig. 1) is an adequate substrate for this purpose. Uric acid is a terminal metabolite of purine in primates including humans. It is also a water-soluble antioxidant that can scavenge many types of ROS: free radicals, ${ }^{(9)}$ peroxynitrite $\left(\mathrm{ONOO}^{-}\right),{ }^{(10)}$ hypochlorous anion $\left(\mathrm{ClO}^{-}\right),{ }^{(11)}$ and singlet oxygen $\left({ }^{1} \mathrm{O}_{2}\right) \cdot{ }^{(9)}$ Furthermore, its oxidation products are specific to the ROS (Fig. 1): free radical-induced oxidation gives allantoin $(\mathrm{AL}) ;^{(12)} \mathrm{ONOO}^{-}$-induced oxidation yields triuret; ${ }^{(13)}$ and nitric oxide ('NO) gives 6-aminouracil. ${ }^{(14)}$ However, the ${ }^{1} \mathrm{O}_{2}$ induced-oxidation product has not been identified.

Singlet oxygen $\left({ }^{1} \mathrm{O}_{2}\right)$ is a prominent ROS that plays an important role in bactericidal action. Nakano et al. ${ }^{(15)}$ showed that ${ }^{1} \mathrm{O}_{2}$ killed $E$. coli effectively, although it was not harmful against human umbilical vein endothelial cells. Because the respiratory chains of eukaryotic cells are enclosed in mitochondria, whereas those of prokaryotic cells are contained in the cell membrane, ${ }^{1} \mathrm{O}_{2}$ penetrating from the cell surface turns into harmless triplet molecular oxygen $\left({ }^{3} \mathrm{O}_{2}\right)$ before it reaches the mitochondria. Therefore, ${ }^{1} \mathrm{O}_{2}$ can be considered a relatively innocuous ROS against eukaryotic cells. However, an excess amount of ${ }^{1} \mathrm{O}_{2}$ can damage organisms, and some reports indicate that it causes oxidative damage to lipids, ${ }^{(16)}$ proteins, ${ }^{(17)}$ and DNA, ${ }^{(18)}$ and also induces apoptosis. ${ }^{(19)}$ Photosensitization is usually used to produce ${ }^{1} \mathrm{O}_{2}$, but two-electron oxidation of $\mathrm{H}_{2} \mathrm{O}_{2}$ also can generate ${ }^{1} \mathrm{O}_{2} \cdot{ }^{(20)}$ The oxidation of $\mathrm{H}_{2} \mathrm{O}_{2}$ mimics myeloperoxidase (MPO), which produces $\mathrm{ClO}^{-}$from $\mathrm{H}_{2} \mathrm{O}_{2}$ and $\mathrm{Cl}^{-}$. The $\mathrm{ClO}^{-}$anion is a strong oxidant that can oxidize $\mathrm{H}_{2} \mathrm{O}_{2}$ to ${ }^{1} \mathrm{O}_{2}$, ${ }^{(21)}$ which suggests that ${ }^{1} \mathrm{O}_{2}$ production may occur in vivo without sunlight exposure.

The current study demonstrated that parabanic acid (PA, Fig. 1) was formed specifically by ${ }^{1} \mathrm{O}_{2}$-induced UA oxidation. Production of ${ }^{1} \mathrm{O}_{2}$ resulted from thermal decomposition of 3-(1,4-dihydro-1,4epidioxy-4-methyl-1-naphthyl)propionic acid (NEPO), photooxidation using Rose Bengal, and $\mathrm{H}_{2} \mathrm{O}_{2}$ oxidation by $\mathrm{ClO}^{-}$or $\mathrm{ONOO}^{-}$, and $\mathrm{PA}$ was produced in high yield. However, the yield of PA was less than a few percent from peroxyl radical-, $\mathrm{ClO}^{-}$- or $\mathrm{ONOO}^{-}$-induced oxidation of UA. These results strongly suggest that PA is an oxidation product specific to ${ }^{1} \mathrm{O}_{2}$ oxidation, and that PA and its hydrolysis product, oxaluric acid (OUA, Fig. 1), are suitable indicators of ${ }^{1} \mathrm{O}_{2}$ production in vivo.

\section{Materials and Methods}

Chemicals. UA, PA, and other chemicals were purchased from Wako Pure Chemical Industries, Co., Ltd. (Osaka, Japan), Tokyo Chemical Industry Co., Ltd. (Tokyo, Japan), or Waken B Tech Co, Ltd. (Kyoto, Japan), and used as received. An $\mathrm{ONOO}^{-}$generator, 3-(4-morpholinyl)sydnonimine hydrochloride (SIN-1), was purchased from Dojindo (Kumamoto, Japan). Authentic standard solutions of UA and PA were dissolved in $100 \mathrm{mM}$ phosphate buffer ( $\mathrm{pH} 7.4$ ) and methanol, respectively, and stored at $4^{\circ} \mathrm{C}$ until use. The OUA was prepared by hydrolysis of PA upon addition of aqueous $\mathrm{NH}_{3}$ and then the solution was neutralized using $1 \mathrm{M}$ $\mathrm{HCl}$. The OUA formation was confirmed by LC/time-of-flight mass spectrometry (TOFMS) analysis using an ion corresponding to OUA $(m / z=-131)$ and its fragment ion $(m / z=-59)$.

$\mathrm{ONOO}^{-}$was synthesized using a modified procedure described by Kato et al. (22) Briefly, an ice-cold $0.7 \mathrm{M} \mathrm{H}_{2} \mathrm{O}_{2}$ solution containing $0.6 \mathrm{M} \mathrm{HCl}(10 \mathrm{ml})$ was added to a well-stirred $0.6 \mathrm{M}$ $\mathrm{NaNO}_{2}$ solution $(10 \mathrm{ml})$ in an ice bath, immediately followed by addition of $1.5 \mathrm{M} \mathrm{NaOH}(20 \mathrm{ml})$. The excess $\mathrm{H}_{2} \mathrm{O}_{2}$ was removed by addition of $\mathrm{MnO}_{2}$. The solution was then frozen at $-25^{\circ} \mathrm{C}$. The $\mathrm{ONOO}^{-}$formed a yellow top layer due to frozen fractionation. This layer was collected and its concentration was determined as $330 \mathrm{mM}$ by measuring its UV absorbance at $302 \mathrm{~nm}$ $\left(\varepsilon=1,670 \mathrm{M}^{-1} \cdot \mathrm{cm}^{-1}\right)$.

*To whom correspondence should be addressed. E-mail: afujisawa@stf.teu.ac.jp 
Oxidation of UA with ${ }^{1} \mathrm{O}_{2}$ produced from the photoirradiation of Rose Bengal. An aqueous mixture containing $50,100,150$ or $200 \mu \mathrm{M}$ UA and $10 \mu \mathrm{M}$ Rose Bengal was irradiated by UVA light $\left(1.12 \mathrm{~mW} / \mathrm{cm}^{2}\right)$ for $\sim 3 \mathrm{~h}$ until all the UA was consumed. Next, the UVA light was turned off and the reaction solution was left at room temperature for $\sim 9 \mathrm{~h}$. Concentrations of UA and products were analyzed by LC/TOFMS and HPLC as described below.

Oxidation of UA with ${ }^{1} \mathrm{O}_{2}$ produced from NEPO. Thermal decomposition of NEPO produces ${ }^{1} \mathrm{O}_{2}$. The purity of the NEPO was determined as $78 \%$ by the comparison of the UV absorption at $288 \mathrm{~nm}$ before and after the thermal decomposition of a methanolic solution of NEPO. Most of the NEPO was decomposed within $3 \mathrm{~h}$ at $35^{\circ} \mathrm{C}$. A mixture of 50 or $100 \mu \mathrm{M}$ UA and $8.0 \mathrm{mM}$ NEPO in $50 \%$ aqueous methanol was incubated at $35^{\circ} \mathrm{C}$ for 3 or $12 \mathrm{~h}$. Concentrations of UA and products were analyzed by LC/MS/MS and HPLC as described below.

Oxidation of UA with ${ }^{1} \mathrm{O}_{2}$ produced from $\mathrm{H}_{2} \mathrm{O}_{2}$ and $\mathrm{NaClO}$

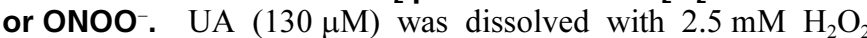
in $100 \mathrm{mM}$ phosphate buffer (pH 7.4) containing $100 \mu \mathrm{M}$ diethylenetriamine- $N, N, N^{\prime}, N^{\prime \prime}, N^{\prime \prime}$-pentaacetic acid (DTPA) for chelation of transition metal ions. Next, $33 \mu \mathrm{l}$ of $182 \mathrm{mM}$ aqueous $\mathrm{NaClO}$ solution was added into $20 \mathrm{ml}$ of the well-stirred reaction mixture at a constant rate $(2 \mu \mathrm{M} \mathrm{NaClO} / \mathrm{min})$ using a syringe pump (Harvard Apparatus, Holliston, MA) over $2.5 \mathrm{~h}$.

A methanolic SIN-1 solution $(100 \mathrm{mM})$ or an aqueous $\mathrm{ONOO}^{-}$ solution $(330 \mathrm{mM})$ was added to $100 \mathrm{mM}$ phosphate buffer (pH 7.4) containing $150 \mu \mathrm{M} \mathrm{UA}, 2.5 \mathrm{mM} \mathrm{H}_{2} \mathrm{O}_{2}$, and $100 \mu \mathrm{M}$ DTPA and incubated at room temperature for $3 \mathrm{~h}$.

In the absence of $\mathrm{H}_{2} \mathrm{O}_{2}$, the oxidation of UA by $\mathrm{NaClO}$ or $\mathrm{ONOO}^{-}$was carried out at room temperature for $3 \mathrm{~h}$. Concentrations of UA and products were determined by HPLC as described below.
UA oxidation by peroxyl radicals from 2',2-azobis(2amidinopropane) dihydrochloride (AAPH). A mixture of $150 \mu \mathrm{M}$ UA and $10 \mathrm{mM}$ AAPH in phosphate buffer solution (pH 7.4) containing $100 \mu \mathrm{M}$ DTPA was incubated at $37^{\circ} \mathrm{C}$ for $3 \mathrm{~h}$. Concentrations of UA and products were determined by HPLC as described below.

Hydrolysis of PA to OUA. Phosphate buffers at $\mathrm{pH} 4.0$ to 8.5 were prepared by adding $1 \mathrm{M} \mathrm{NaOH}$ or $1 \mathrm{M} \mathrm{H}_{3} \mathrm{PO}_{4}$ to the buffer solutions. Each $500 \mu \mathrm{M}$ PA solution at various pHs was incubated under aerobic conditions at room temperature for $6 \mathrm{~h}$. Concentrations of UA and OUA were determined by HPLC as described below.

PA detection on human skin surface. Five healthy volunteers participated in this study after giving informed consent. Skin surface UA and OUA were collected from their forearms before and after exposure to sunlight for $2 \mathrm{~h}$. The collection procedure was as follows. Five glass tubes containing $1.0 \mathrm{ml}$ of methanol were prepared. The open end of each tube $(\varnothing 20 \mathrm{~mm})$ was pressed tightly against the skin at different locations on the forearm and then rotated carefully to allow the methanol to contact the skin for $1 \mathrm{~min}$. The extracts were combined and the solvent removed using a nitrogen gas flow. The residue was re-dissolved into methanol and analyzed using LC/MS/MS.

HPLC analysis. The amounts of UA and its oxidative metabolites, PA, OUA, and AL, were determined by monitoring the absorption at $210 \mathrm{~nm}$ using a reversed-phase HPLC. The mobile phase was aqueous ammonium acetate $(40 \mathrm{mM})$ and delivered at a rate of $1.0 \mathrm{ml} / \mathrm{min}$. An ODS column (Tosoh, Tokyo, Japan; $5 \mu \mathrm{m}, 4.6 \mathrm{~mm} \times 250 \mathrm{~mm}$ ) or a Develosil C30-UG (Nomura Chemical Co., Ltd., Tokyo, Japan; $5 \mu \mathrm{m}, 250 \mathrm{~mm} \times 4.6 \mathrm{~mm}$ ) was used for separation. Retention times for UA, PA, OUA and AL were 7.8, 3.2, 11.0 and $2.5 \mathrm{~min}$, respectively, using the ODS column, and 14.0, 7.0, 11.5 and $4.1 \mathrm{~min}$, respectively, using the C-30 column.<smiles>Nc1cc(=O)[nH]c(=O)[nH]1</smiles>
6-Aminouracil<smiles>NC(=O)NC1NC(=O)NC1=O</smiles>

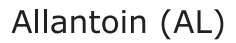<smiles>FC(Cl)(Cl)C(Cl)(Cl)Cl</smiles><smiles>[14CH3]N=O</smiles><smiles>O=c1[nH]c(=O)c2[nH]c(=O)[nH]c2[nH]1</smiles>

Uric acid (UA)

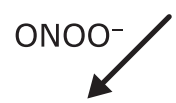<smiles>NC(=O)NC(=O)NC(N)=O</smiles>

Triuret<smiles>O=C1NC(=O)C(=O)N1</smiles>

Parabanic acid (PA) Hydrolysis<smiles>NC(=O)NC(=O)C(=O)O</smiles>

Oxaluric acid (OUA)

Fig. 1. Reported oxidation products of UA induced by reactive oxygen species: AL is produced by free radical-induced oxidation; triuret by ONOO-; 6-aminouracil by ${ }^{*} \mathrm{NO}$; and $\mathrm{PA}$ by ${ }^{1} \mathrm{O}_{2}$ (this study). 
LC/TOFMS analysis. To obtain accurate mass-to-charge ratios $(\mathrm{m} / \mathrm{z})$ of UA oxidative metabolites, HPLC combined with TOFMS (JMS-T100LC, JEOL Ltd., Tokyo, Japan) was used. Negative ionization was performed at an ionization potential of
$-2,000 \mathrm{~V}$. The optimized applied voltages to the ring lens, outer orifice, inner orifice, and ion guide were $-5 \mathrm{~V},-10 \mathrm{~V},-5 \mathrm{~V}$ and $-500 \mathrm{~V}$ respectively. To obtain accurate $\mathrm{m} / \mathrm{z}$ values, trifluoroacetic acid (TFA) was used as an internal standard for $\mathrm{m} / \mathrm{z}$ calibration.
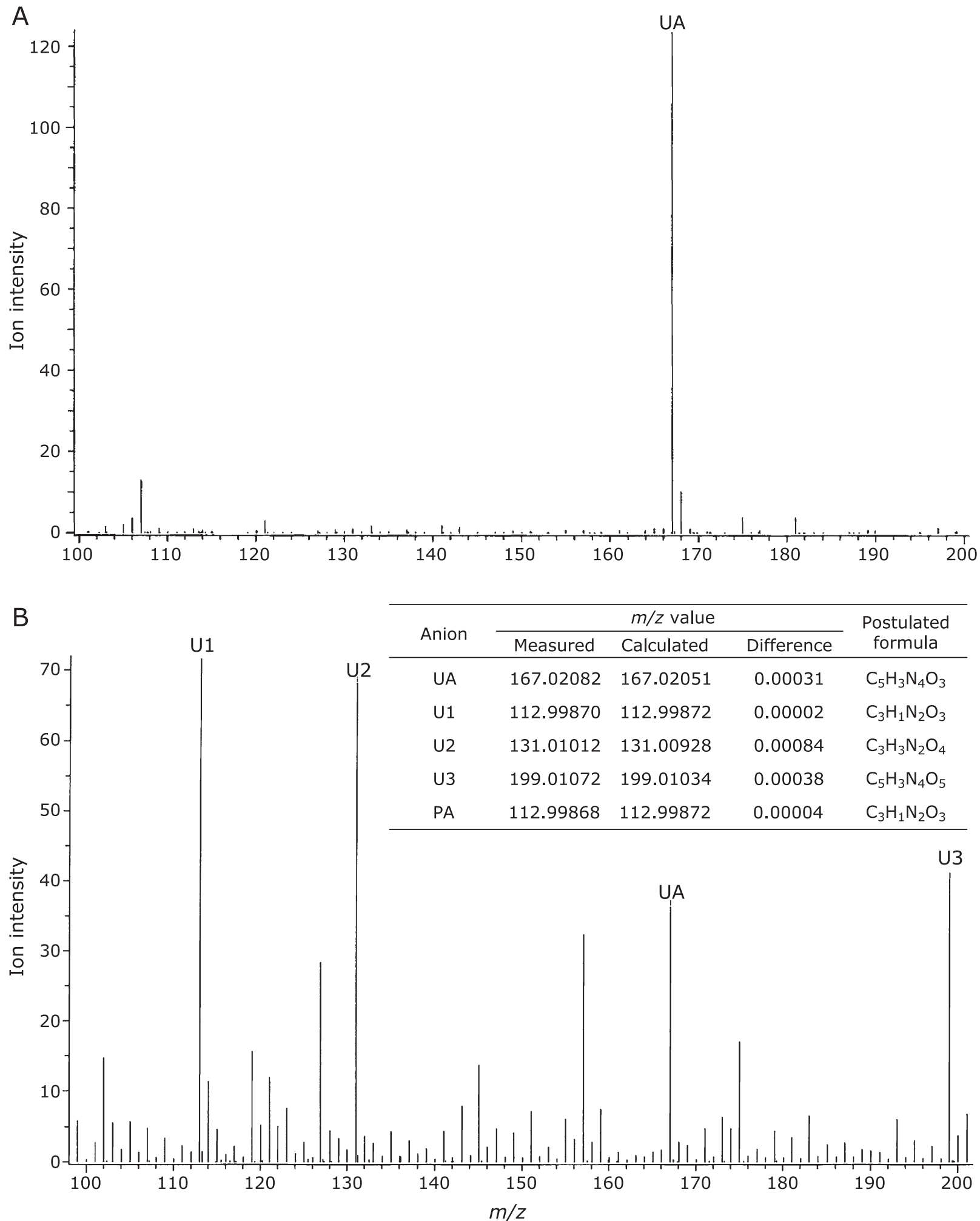

Fig. 2. MS spectra of $200 \mu \mathrm{M}$ UA (A) before and (B) after 60 -min photooxidation induced by UVA irradiation $\left(1.12 \mathrm{~mW} / \mathrm{cm}^{2}\right)$ using $10 \mu \mathrm{M}$ Rose Bengal as a sensitizer. The TOFMS analysis was conducted in negative ESI mode with an ionization potential of $-2,000 \mathrm{~V}$. The measured $m / z$ values were corrected using TFA as an internal standard. The chemical formula of PA and its candidates of U1, U2 and U3 are shown in the insert table with measured and calculated $\mathrm{m} / \mathrm{z}$ values. 
LC/MS/MS analysis. An LC/MS/MS system (LCMS-8040, Shimadzu, Kyoto, Japan) was used to determine the amounts of PA and OUA at the picomole level. Aqueous formic acid $(0.2 \mathrm{ml} / \mathrm{min}, \mathrm{pH} 3.5)$ was used as the mobile phase with a Develosil C30-UG column (Nomura Chemical Co., Ltd., Tokyo, Japan; $5 \mu \mathrm{m}, 250 \mathrm{~mm} \times 2.0 \mathrm{~mm}$ ). Negative ionization was performed at $-3.2 \mathrm{kV}$ using an electrospray probe. For identification and quantification of each compound, multiple reaction monitoring (MRM) measurements were obtained. Optimized combinations of product and precursor ions for PA and OUA were determined as $-42 /-113$ and $-59 /-131$ respectively. Chromatographic retention times for PA and OUA were 6.0 and $10.5 \mathrm{~min}$, respectively.

\section{Results and Discussion}

Identification of ${ }^{1} \mathrm{O}_{2}$-induced oxidation products of UA. ${ }^{1} \mathrm{O}_{2}$ was produced from UVA irradiated $10 \mu \mathrm{M}$ Rose Bengal. Figure 2 shows the changes in the MS spectra in the presence of $200 \mu \mathrm{M}$ UA before (Fig. 2A) and $60 \mathrm{~min}$ after irradiation (Fig. 2B), as determined by negative electrospray ionization (ESI) mode TOFMS. The UA concentration was reduced to $35 \%$ and three unidentified anions, U1, U2 and U3, appeared in the MS spectrum after $60 \mathrm{~min}$. These products were not seen in the absence of UA, suggesting they were derived from UA. The $\mathrm{m} / \mathrm{z}$ value of $U 1$ was determined to be -112.99870 using TFA as an internal standard, and its chemical formula was postulated to be $\mathrm{C}_{3} \mathrm{HN}_{2} \mathrm{O}_{3}$. This chemical formula is identical with that of PA and the $m / z$ value of authentic PA is -112.99868 . Furthermore, the retention times of $\mathrm{U} 1$ and authentic PA were identical (data not shown). We therefore concluded that U1 is PA.

The chemical formula of $\mathrm{U} 2$ was also determined to be $\mathrm{C}_{3} \mathrm{H}_{4} \mathrm{~N}_{2} \mathrm{O}_{4}$, by its $m / z$ value. This chemical formula is identical with OUA, a hydrolysate of PA. The retention times and MS spectra of $\mathrm{U} 2$ and authentic OUA were identical (data not shown), indicating that $\mathrm{U} 2$ is OUA. U3 $\left(\mathrm{C}_{5} \mathrm{H}_{4} \mathrm{~N}_{4} \mathrm{O}_{5}\right)$ was shown to be an $\mathrm{O}_{2}$ adduct of UA.

Hydrolysis of PA to OUA. The effect of $\mathrm{pH}$ on the stability of aqueous PA was examined. The rates of PA hydrolysis and OUA formation increased with increasing $\mathrm{pH}$ (Fig. 3). The formation of OUA was stoichiometric with the decomposition of PA. The OUA formed was stable in solution at all pHs (4-8.5) for at least 1 week (data not shown).

The above results indicate that the ${ }^{1} \mathrm{O}_{2}$-induced oxidation products of UA are PA and its hydrolysate OUA. We next examined whether this is true in other ${ }^{1} \mathrm{O}_{2}$ formation systems such as thermal decomposition of NEPO and $\mathrm{H}_{2} \mathrm{O}_{2}$ plus $\mathrm{ClO}^{-}$ or $\mathrm{ONOO}^{-}$.

Time course changes in PA and OUA levels during the oxidation of UA in various ${ }^{1} \mathrm{O}_{2}$ production systems. First, we employed NEPO which gives ${ }^{1} \mathrm{O}_{2}$ by its thermal decomposition. Figure 4A shows time course changes in UA, PA and OUA when $100 \mu \mathrm{M}$ UA and $8 \mathrm{mM} \mathrm{NEPO}$ were incubated in methanol/water $(50 / 50)$ at $35^{\circ} \mathrm{C}$ for $3 \mathrm{~h}$. The major product was PA with a little OUA. The total yield of PA and OUA to consumed UA was $66.6 \%$. When $1 \mathrm{mM} \mathrm{NaN}{ }_{3}$, an ${ }^{1} \mathrm{O}_{2}$ scavenger, was added to the reaction system, the rates of UA consumption and $\mathrm{PA}$ formation were reduced (Fig. 4B). The total yield of PA and OUA was also reduced to $13.2 \%$, indicating that ${ }^{1} \mathrm{O}_{2}$ is a key oxidant of UA. All the NEPO was decomposed within $4 \mathrm{~h}$ at $35^{\circ} \mathrm{C}$. However we incubated the reaction solution for another $9 \mathrm{~h}$ and found an increase of PA and OUA formation (Table 1), indicating that intermediates such as U3 slowly decomposed to PA. Therefore, the total yield of PA and OUA increased to $99.1 \%$, indicating that PA and OUA are the exclusive products of ${ }^{1} \mathrm{O}_{2}$-induced oxidation of UA. This was also the case in the UVA-irradiated Rose Bengal system (Fig. 5A and Table 1).

Since all NEPO was converted to ${ }^{1} \mathrm{O}_{2}$, we knew how much ${ }^{1} \mathrm{O}_{2}$ was produced. We could then calculate the ratio of the amount of UA consumed to the total amount of ${ }^{1} \mathrm{O}_{2}$ generated in the system. This ratio was $1 / 370$ or $1 / 180$, respectively, when 50 or $100 \mu \mathrm{M}$ UA was oxidized (Table 1), indicating that ${ }^{1} \mathrm{O}_{2}$ was predominantly quenched physically by UA or solvents. In fact, the rate constant for the quenching of ${ }^{1} \mathrm{O}_{2}$ by UA was reported to be $3.6 \times 10^{8} \mathrm{M}^{-1} \cdot \mathrm{s}^{-1}$, (23) while the rate constant for the reaction of ${ }^{1} \mathrm{O}_{2}$ with UA was determined to be $2.3 \times 10^{6} \mathrm{M}^{-1} \cdot \mathrm{s}^{-1}$. (24)

The mechanism of PA formation remains unclear. The isolated U3 decomposed under neutral conditions to form PA (data not shown), suggesting that U3 is a direct precursor of PA formation. Identification of $\mathrm{U} 3$ is under investigation.

Hydrogen peroxide is known to be converted to ${ }^{1} \mathrm{O}_{2}$ by the reaction with $\mathrm{ClO}^{-}{ }^{(20,21)}$ To confirm this, we incubated aqueous UA in the presence of $\mathrm{H}_{2} \mathrm{O}_{2}$ with $\mathrm{ClO}^{-}$. Figure $5 \mathrm{~B}$ shows the time course changes in UA, PA and OUA when $130 \mu \mathrm{M}$ UA was incubated with $2.5 \mathrm{mM} \mathrm{H}_{2} \mathrm{O}_{2}$ and $\mathrm{NaClO}$. $\mathrm{NaClO}$ was added at a rate of $2 \mu \mathrm{M} / \mathrm{min}$ from $30 \mathrm{~min}$. Thereafter, UA was decreased and PA was increased. The total yield of PA and OUA reached $56.1 \%$ for $2.5 \mathrm{~h}$ oxidation. In the absence of $\mathrm{H}_{2} \mathrm{O}_{2}$, the rate of UA consumption was slower and a little formation of PA and OUA (1.3\% yield) was observed (Table 1 and Fig. 5E). These results suggest that $\mathrm{ClO}^{-}$-induced oxidation of UA only produced slight PA and OUA and $\mathrm{ClO}^{-}$converted $\mathrm{H}_{2} \mathrm{O}_{2}$ to ${ }^{1} \mathrm{O}_{2}$.
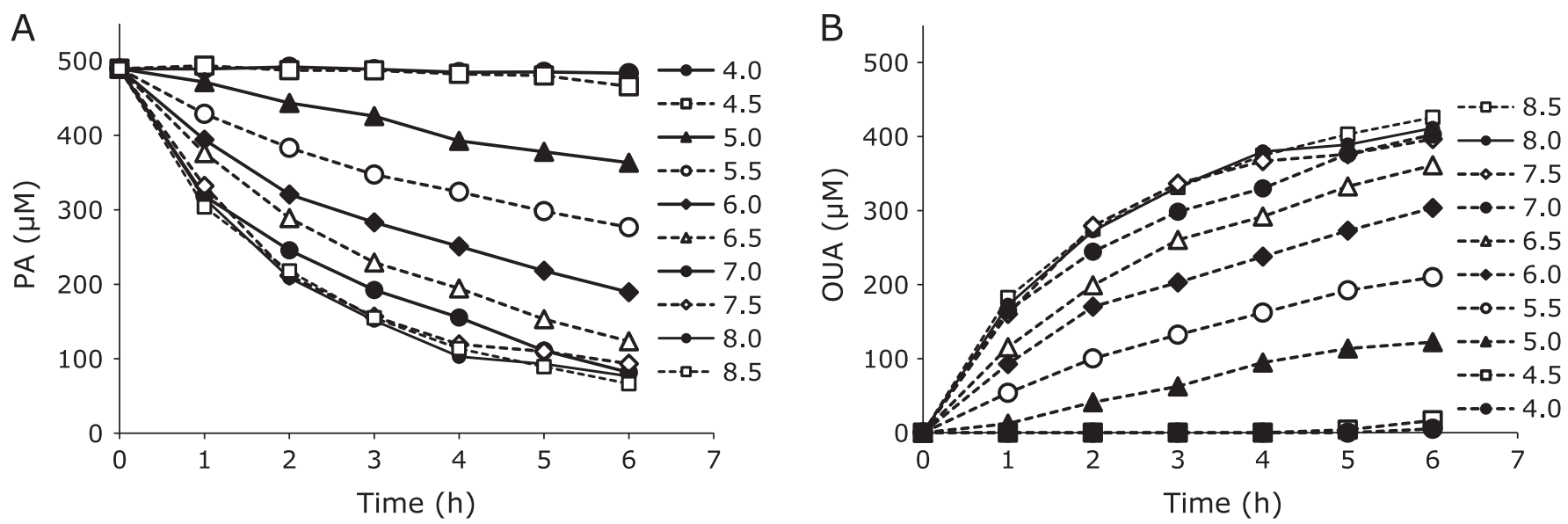

Fig. 3. Hydrolysis of (A) PA to (B) OUA at room temperature at various pHs (4.0-8.5). 

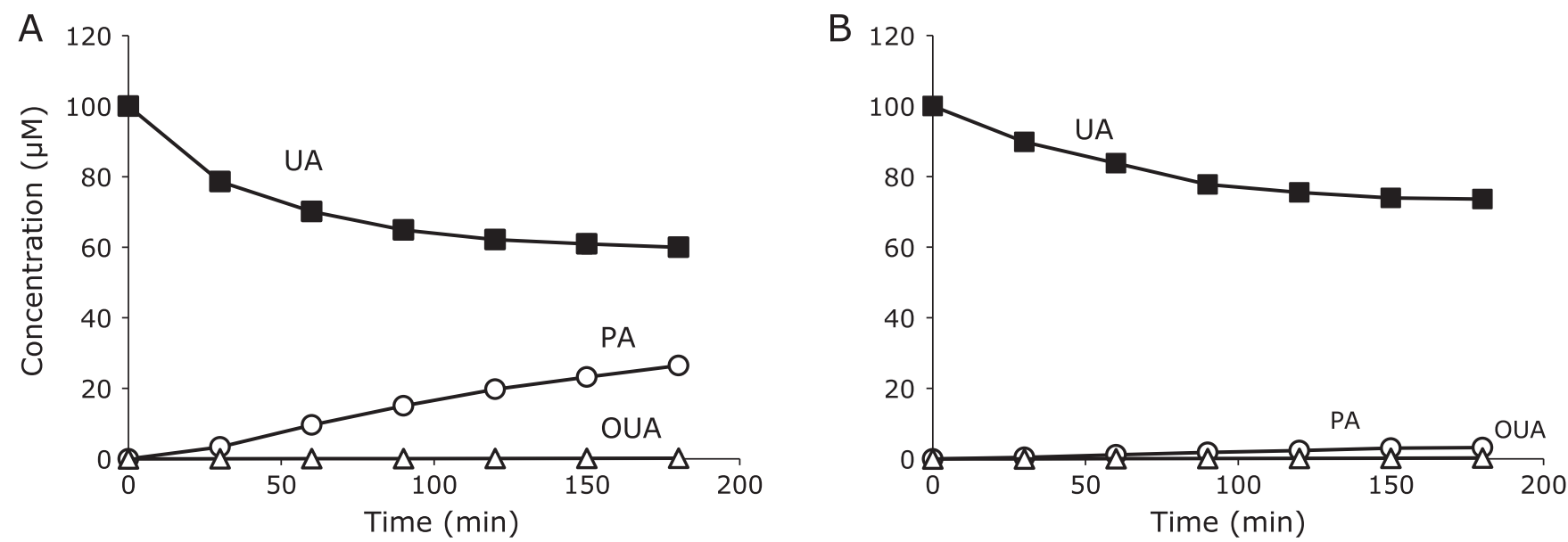

Fig. 4. Oxidation of $100 \mu \mathrm{M}$ UA ( $\square$ ) in methanol/ $\mathrm{H}_{2} \mathrm{O}=50 / 50$ by ${ }^{1} \mathrm{O}_{2}$ derived from $8.0 \mathrm{mM} \mathrm{NEPO}$ at $35^{\circ} \mathrm{C}$ and the formation of $\mathrm{PA}(\bigcirc)$ and $\mathrm{OUA}(\triangle)$ in the absence $(\mathrm{A})$ and in the presence $(\mathrm{B})$ of $1.0 \mathrm{mM} \mathrm{NaN}_{3}$. All data are expressed as mean $\pm \mathrm{SD}(n=3)$.

Table 1. Formation of PA and OUA and their yields during UA oxidation induced by different types of ROS [ $\mu \mathrm{M}$, mean \pm SD $(n=3)$ ]

\begin{tabular}{|c|c|c|c|c|c|c|c|}
\hline ROS & {$[\mathrm{UA}]_{0}$} & Time (h) & $-\Delta[\mathrm{UA}]$ & [PA] & [OUA] & {$[\mathrm{PA}]+[\mathrm{OUA}]$} & Yield (\%) \\
\hline${ }^{1} \mathrm{O}_{2}$ from $8.0 \mathrm{mM}$ NEPO & 50 & 12 & $21.3 \pm 1.3$ & $20.4 \pm 1.3$ & $0.29 \pm 0.07$ & $20.7 \pm 1.4$ & $97.0 \pm 2.0$ \\
\hline${ }^{1} \mathrm{O}_{2}$ from $8.0 \mathrm{mM}$ NEPO & 100 & 3 & $40.0 \pm 2.2$ & $26.4 \pm 0.9$ & $0.18 \pm 0.01$ & $26.6 \pm 0.9$ & $66.6 \pm 1.3$ \\
\hline${ }^{1} \mathrm{O}_{2}$ from $8.0 \mathrm{mM} \mathrm{NEPO}+1.0 \mathrm{mM} \mathrm{NaN}_{3}$ & 100 & 3 & $26.4 \pm 0.4$ & $3.21 \pm 0.04$ & $0.25 \pm 0.01$ & $3.5 \pm 0.04$ & $13.2 \pm 0.2$ \\
\hline${ }^{1} \mathrm{O}_{2}$ from $8.0 \mathrm{mM}$ NEPO & 100 & 12 & $44.6 \pm 1.1$ & $42.4 \pm 0.8$ & $0.57 \pm 0.13$ & $44.2 \pm 1.2$ & $99.1 \pm 0.3$ \\
\hline${ }^{1} \mathrm{O}_{2}$ from UVA-irradiated Rose Bengal & 50 & 12 & 50 & $7.2 \pm 0.2$ & $41.6 \pm 0.4$ & $48.8 \pm 0.4$ & $97.6 \pm 0.8$ \\
\hline${ }^{1} \mathrm{O}_{2}$ from UVA-irradiated Rose Bengal & 100 & 12 & 100 & $18.3 \pm 0.4$ & $78.6 \pm 0.5$ & $96.9 \pm 0.2$ & $96.9 \pm 0.2$ \\
\hline${ }^{1} \mathrm{O}_{2}$ from UVA-irradiated Rose Bengal & 150 & 12 & 150 & $33.1 \pm 0.2$ & $109.4 \pm 0.1$ & $142.5 \pm 0.3$ & $95.0 \pm 0.2$ \\
\hline${ }^{1} \mathrm{O}_{2}$ from UVA-irradiated Rose Bengal & 200 & 2 & $157 \pm 3.4$ & $89.7 \pm 3.6$ & $1.9 \pm 1.4$ & $91.7 \pm 5.0$ & $58.4 \pm 4.3$ \\
\hline${ }^{1} \mathrm{O}_{2}$ from UVA-irradiated Rose Bengal & 200 & 12 & 200 & $55.7 \pm 0.7$ & $129.8 \pm 0.1$ & $185.4 \pm 0.7$ & $92.7 \pm 0.4$ \\
\hline${ }^{1} \mathrm{O}_{2}$ from $2.5 \mathrm{mM} \mathrm{H}_{2} \mathrm{O}_{2}+300 \mu \mathrm{M} \mathrm{ClO}^{-}$ & 130 & 2.5 & $127 \pm 0.5$ & $70.9 \pm 3.8$ & $0.12 \pm 0.003$ & $71.0 \pm 3.8$ & $56.1 \pm 3.3$ \\
\hline${ }^{1} \mathrm{O}_{2}$ from $2.5 \mathrm{mM} \mathrm{H}_{2} \mathrm{O}_{2}+\mathrm{ONOO}^{-}(1.0 \mathrm{mM} \mathrm{SIN-1)}$ & 150 & 3 & 150 & $0.04 \pm 0.01$ & $56.2 \pm 0.3$ & $56.3 \pm 0.3$ & $37.0 \pm 0.2$ \\
\hline Peroxyl radicals from $10 \mathrm{mM}$ AAPH & 150 & 3 & $85.9 \pm 4.2$ & $1.2 \pm 0.1$ & $0.5 \pm 0.1$ & $1.7 \pm 0.1$ & $1.9 \pm 0.1$ \\
\hline $\mathrm{ClO}^{-}(360 \mu \mathrm{M})$ & 260 & 3 & $243 \pm 9.9$ & $1.6 \pm 0.2$ & $1.5 \pm 0.2$ & $3.1 \pm 0.2$ & $1.3 \pm 0.1$ \\
\hline $\mathrm{ONOO}^{-}(1.0 \mathrm{mM}$ SIN-1) & 200 & 3 & $132 \pm 15$ & ND & ND & ND & 0 \\
\hline
\end{tabular}

ROS, reactive oxygen species; UA, uric acid; PA, parabanic acid; OUA, oxaluric acid; NEPO, 3-(1,4-dihydro-1,4-epidioxy-4-methyl-1-naphthyl)propionic acid; SIN-1, 3-(4-morpholinyl)sydnonimine, hydrochloride; ND, not detected.

Similarly, $\mathrm{ONOO}^{-}$converts $\mathrm{H}_{2} \mathrm{O}_{2}$ to ${ }^{1} \mathrm{O}_{2} \cdot{ }^{(25,26)}$ Figure $5 \mathrm{C}$ shows the time course changes in UA, PA and OUA when $150 \mu \mathrm{M}$ UA was incubated with $2.5 \mathrm{mM} \mathrm{H}_{2} \mathrm{O}_{2}$ and $1.0 \mathrm{mM} \mathrm{SIN-}^{-1}$, an $\mathrm{ONOO}^{-}$ generator. The major product was OUA rather than PA because the $\mathrm{pH}$ of the reaction solution was $\sim 8$ which accelerated the hydrolysis of PA. The total yield of PA and OUA reached $37.0 \%$ for $3 \mathrm{~h}$ oxidation. In the absence of $\mathrm{H}_{2} \mathrm{O}_{2}$, the rate of UA consumption became slower and no formation of PA and OUA ( $0 \%$ yield) was observed (Table 1 and Fig. 5F). These results suggest that $\mathrm{ONOO}^{-}$-induced oxidation of UA produced no PA and OUA and $\mathrm{ONOO}^{-}$converted $\mathrm{H}_{2} \mathrm{O}_{2}$ to ${ }^{1} \mathrm{O}_{2}$. It is noteworthy that similar results were obtained when synthetic $\mathrm{ONOO}^{-}$was used instead of SIN-1 (data not shown).

Oxidation of UA induced by peroxyl radical, $\mathrm{ClO}^{-}$, or

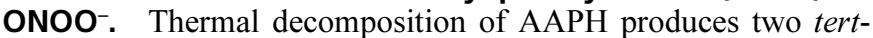
carbon-centered radicals which are immediately converted to two tert-peroxyl radicals. Peroxyl radical-induced oxidation of aqueous UA resulted in UA decay and AL formation (Fig. 5D). The total yield of PA and OUA was only $1.9 \%$ but this was significant. This may suggest that a small amount of ${ }^{1} \mathrm{O}_{2}$ was formed by the termination of two tert-peroxyl radicals, ${ }^{(27)}$ and/or the Russellreaction of two methylperoxyl radicals formed by $\beta$-scission of tert-alkoxyl radical occurred. ${ }^{(27-29)}$ However, this requires further investigation.

As shown before, the total yield of PA and $\mathrm{OUA}_{\mathrm{A}}$ in $\mathrm{ClO}^{-}$and $\mathrm{ONOO}^{-}$-induced oxidation of UA was below $2 \%$. Therefore, we concluded that PA is the ${ }^{1} \mathrm{O}_{2}$ specific oxidation product of uric acid. We next tried to detect PA in biological samples.

Detection of PA on human skin surface. Human skin surface was selected as a candidate of PA detection since UA is present there and the level of squalene hydroperoxide $\left({ }^{1} \mathrm{O}_{2}\right.$ oxidation product of squalene) increases after sunlight exposure. ${ }^{(30)}$ Methanol extracts of human skin were analyzed by LC/MS/MS. The analysis revealed the presence of UA and PA in skin lavage samples, but no OUA was detected. It is interesting that the PA and UA levels increased upon sunlight exposure (Table 2). The latter should be a protective response of human skin surface against photooxidation.

We are currently applying this method to human plasma samples. We believe our method is useful to determine the importance of ${ }^{1} \mathrm{O}_{2}$ and its significance in many diseases under oxidative stress. 
A

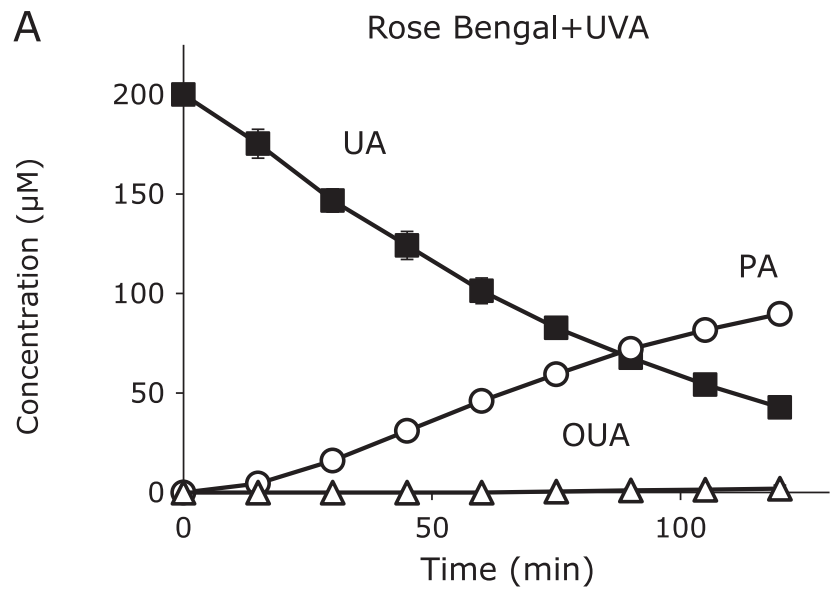

B

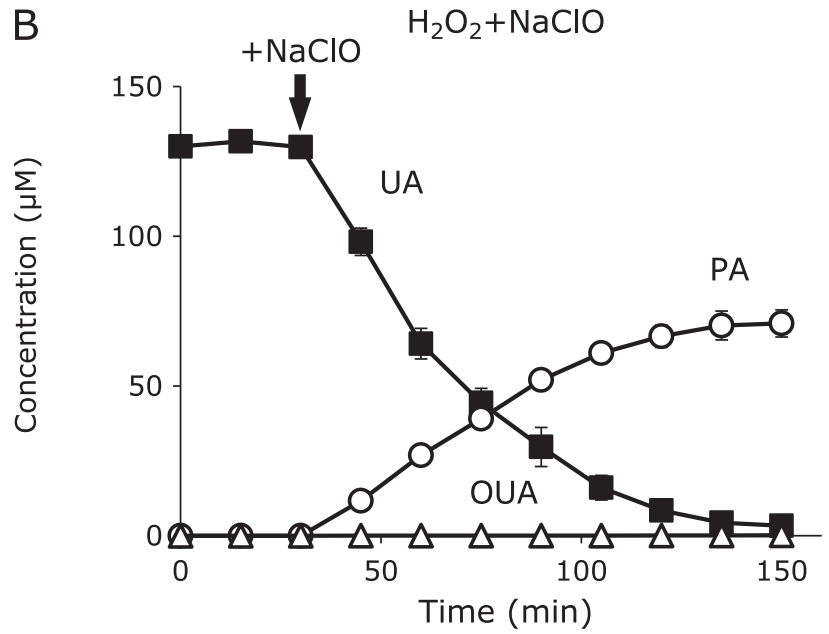

C

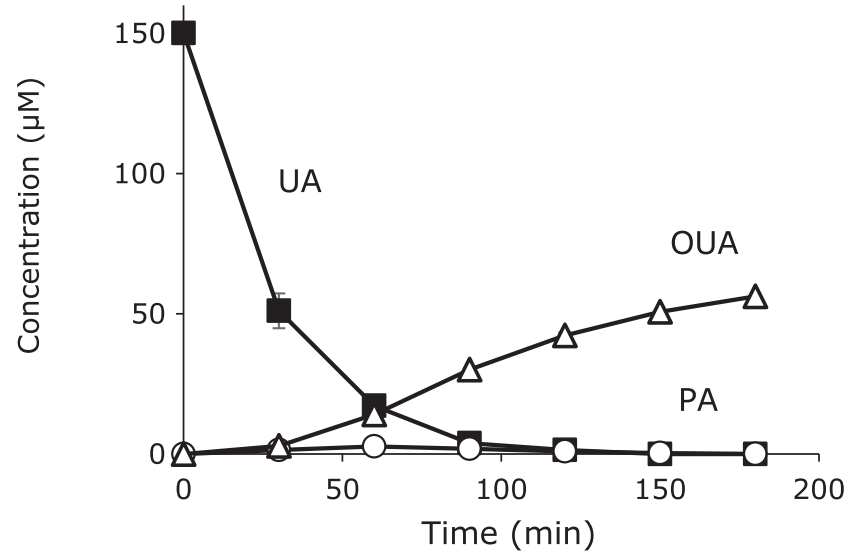

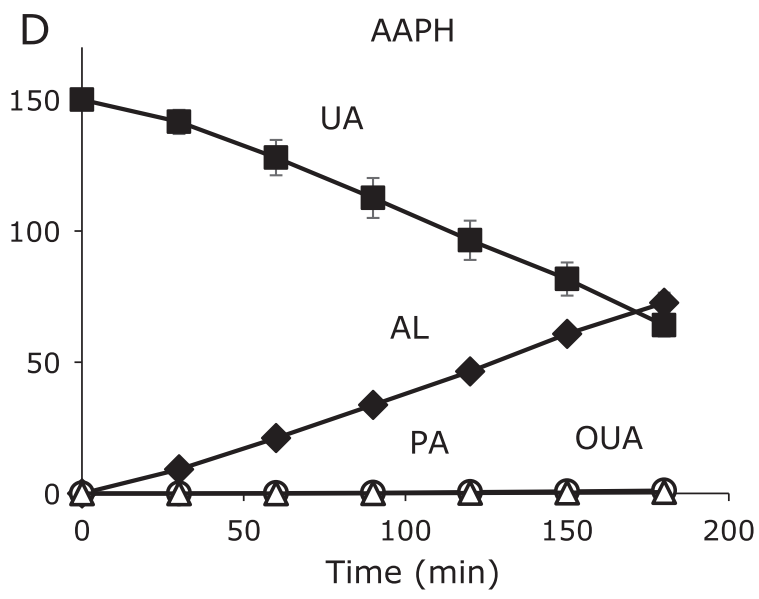

E $\mathrm{NaClO}$

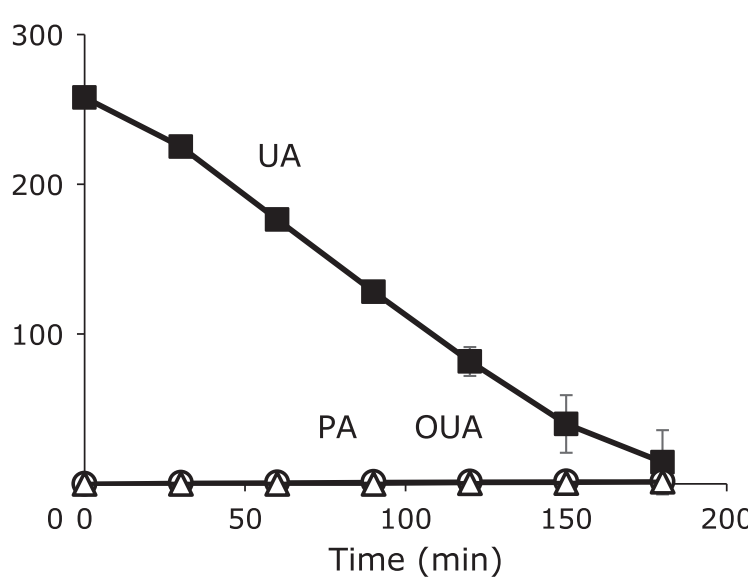

$\mathrm{F} \quad \mathrm{ONOO}^{-}$

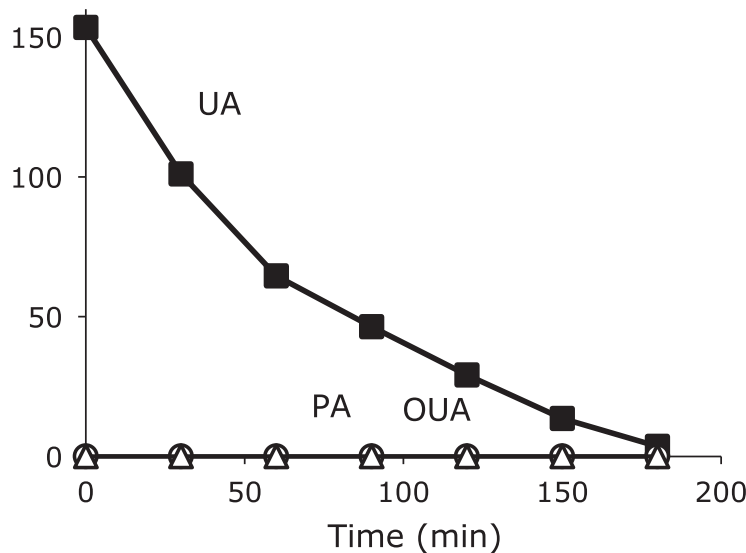

Fig. 5. Oxidation of UA $(\mathbf{\square})$ and the formation of PA $(\bigcirc)$, OUA $(\triangle)$, and AL $(\bullet)$. All data are expressed as mean \pm SD $(n=3)$. (A) UVA-induced photooxidation of $200 \mu \mathrm{M}$ aqueous UA in the presence of $10 \mu \mathrm{M}$ Rose Bengal. (B) Oxidation of $130 \mu \mathrm{M}$ UA by ${ }^{1} \mathrm{O}_{2}$ produced from $2.5 \mathrm{mM} \mathrm{H}_{2} \mathrm{O}_{2}$ and $300 \mu \mathrm{M} \mathrm{NaClO}$ in $100 \mathrm{mM}$ phosphate buffer (pH 7.4) at room temperature. Constant addition of $\mathrm{NaClO}(2 \mu \mathrm{M} / \mathrm{min}) \mathrm{was}$ started at $30 \mathrm{~min}$. (C) Oxidation of $150 \mu \mathrm{M}$ UA by ${ }^{1} \mathrm{O}_{2}$ produced from $2.5 \mathrm{mM} \mathrm{H}_{2} \mathrm{O}_{2}$ and $1.0 \mathrm{mM} \mathrm{SIN-1}$ (ONOO- generator) in $100 \mathrm{mM}$ phosphate buffer (pH 7.4) at room temperature. (D) Oxidation of $150 \mu \mathrm{M}$ aqueous UA with peroxyl radicals produced from $10 \mathrm{mM} \mathrm{AAPH}$ at $37^{\circ} \mathrm{C}$. (E) Oxidation of $260 \mu \mathrm{M}$ UA with $360 \mu \mathrm{M} \mathrm{NaClO}$ in $100 \mathrm{mM}$ phosphate buffer ( $\mathrm{pH} 7.4)$ at room temperature. The addition of NaClO was kept constant (2 $\mu \mathrm{M} / \mathrm{min})$. (F) Oxidation of $190 \mu \mathrm{M}$ UA by $1.0 \mathrm{mM}$ SIN-1 in $100 \mathrm{mM}$ phosphate buffer (pH 7.4) at room temperature.

\section{Conclusions}

We identified PA as the ${ }^{1} \mathrm{O}_{2}$ specific oxidation product of UA. PA is slowly hydrolyzed to OUA under neutral conditions.
Therefore, PA and OUA can serve as novel ${ }^{1} \mathrm{O}_{2}$ markers in vivo. We detected PA on human skin surface and its level increased upon sunlight exposure, indicating that sunlight exposure induced the formation of ${ }^{1} \mathrm{O}_{2}$ on human skin surface. 
Table 2. PA formation and UA secretion on human forearm skin surface exposed to sunlight for $2 \mathrm{~h}$

\begin{tabular}{cccccc}
\hline & $\mathrm{PA}\left(\mathrm{pmol} / \mathrm{cm}^{2}\right)$ & \multicolumn{3}{c}{$\mathrm{UA}\left(\mathrm{pmol} / \mathrm{cm}^{2}\right)$} \\
\hline Before exposure & After exposure & After/Before & Before exposure & After exposure & After/Before \\
\hline $0.020 \pm 0.010$ & $0.065 \pm 0.040^{*}$ & $3.1 \pm 1.2$ & $13.9 \pm 15.1$ & $46.2 \pm 30.8$ & $4.8 \pm 4.2$ \\
\hline
\end{tabular}

PA, parabanic acid; UA, uric acid; Each value represents mean \pm SD $(n=5) ;{ }^{*} p<0.05$.

\section{Abbreviations}

AAPH 2',2-azobis(2-amidinopropane) dihydrochloride

AL allantoin

DTPA diethylenetriamine- $N, N, N^{\prime}, N^{\prime \prime}, N^{\prime \prime}$-pentaacetic acid

ESI electrospray ionization

NEPO 3-(1,4-dihydro-1,4-epidioxy-4-methyl-1-naphthyl) propionic acid

OUA oxaluric acid

PA parabanic acid
ROS reactive oxygen species

SIN-1 3-(4-morpholinyl)sydnonimine, hydrochloride

TFA trifluoroacetic acid

TOFMS time-of-flight mass spectrometry

UA uric acid

\section{Conflict of Interest}

No potential conflicts of interest were disclosed.

\section{References}

1 Flynn TP, Allen DW, Johnson GJ, White JG. Oxidant damage of the lipids and proteins of the erythrocyte membranes in unstable hemoglobin disease. Evidence for the role of lipid peroxidation. J Clin Invest 1983; 71: 12151223.

2 Kasai H, Okada Y, Nishimura S, Rao MS, Reddy JK. Formation of 8hydroxydeoxyguanosine in liver DNA of rats following long-term exposure to a peroxisome proliferator. Cancer Res 1989; 49: 2603-2605.

3 Dukan S, Farewell A, Ballesteros M, Taddei F, Radman M, Nyström T. Protein oxidation in response to increased transcriptional or translational errors. Proc Natl Acad Sci U S A 2000; 97: 5746-5749.

4 Ames BN, Gold LS, Willett WC. The causes and prevention of cancer. Proc Natl Acad Sci US A 1995; 92: 5258-5265.

5 Odegaard AO, Jacobs DR Jr, Sanchez OA, Goff DC Jr, Reiner AP, Gross MD. Oxidative stress, inflammation, endothelial dysfunction and incidence of type 2 diabetes. Cardiovasc Diabetol 2016; 15: 51.

6 Smith MA, Richey Harris PL, Sayre LM, Beckman JS, Perry G. Widespread peroxynitrite-mediated damage in Alzheimer's disease. J Neurosci 1997; 17: 2653-2657.

7 Jaeschke H, Smith CV, Mitchell JR. Reactive oxygen species during ischemia-reflow injury in isolated perfused rat liver. J Clin Invest 1988; 81: 1240-1246.

8 Yamamoto Y, Yamashita S. Plasma ubiquinone to ubiquinol ratio in patients with hepatitis, cirrhosis, and hepatoma, and in patients treated with percutaneous transluminal coronary reperfusion. Biofactors 1999; 9: 241-246.

9 Ames BN, Cathcart R, Schwiers E, Hochstein P. Uric acid provides an antioxidant defense in humans against oxidant- and radical-caused aging and cancer: a hypothesis. Proc Natl Acad Sci US A 1981; 78: 6858-6862.

10 Hooper DC, Spitsin S, Kean RB, et al. Uric acid, a natural scavenger of peroxynitrite, in experimental allergic encephalomyelitis and multiple sclerosis. Proc Natl Acad Sci US A 1997; 95: 675-680.

11 Grootveld M, Halliwell B, Moorhouse CP. Action of uric acid, allopurinol and oxypurinol on the myeloperoxidase-derived oxidant hypochlorous acid. Free Radic Res Commun 1987; 4: 69-76.

12 Kaur H, Halliwell B. Action of biologically-relevant oxidizing species upon uric acid. Identification of uric acid oxidation products. Chem Biol Interact 1990; 73: 235-247.

13 Robinson KM, Morré JT, Beckman JS. Triuret: a novel product of peroxynitrite-mediated oxidation of urate. Arch Biochem Biophys 2004; 423: 213-217.

14 Gersch C, Palii SP, Kim KM, Angerhofer A, Johnson RJ, Henderson GN. Inactivation of nitric oxide by uric acid. Nucleosides Nucleotides Nucleic Acids 2008; 27: 967-978.

15 Nakano M, Kambayashi Y, Tatsuzawa H, Komiyama T, Fujimori K. Useful ${ }^{1} \mathrm{O}_{2}\left({ }^{1} \Delta_{\mathrm{g}}\right)$ generator, 3-(4'-methyl-1'-naphthyl)-propionic acid, 1',4'-endoperoxide
(NEPO), for dioxygenation of squalene (a skin surface lipid) in an organic solvent and bacterial killing in aqueous medium. FEBS Lett 1998; 432: 9-12.

16 Wagner JR, Motchnik PA, Stocker R, Sies H, Ames BN. The oxidation of blood plasma and low density lipoprotein components by chemically generated singlet oxygen. J Biol Chem 1993; 268: 18502-18506.

17 Morgan PE, Dean RT, Davies MJ. Inhibition of glyceraldehyde-3-phosphate dehydrogenase by peptide and protein peroxides generated by singlet oxygen attack. Eur J Biochem 2002; 269: 1916-1925.

18 Ravanat JL, Di Mascio P, Martinez GR, Medeiros MH, Cadet J. Singlet oxygen induces oxidation of cellular DNA. J Biol Chem 2001; 276: 4060140604.

19 Morita A, Werfel T, Stege H, et al. Evidence that singlet oxygen-induced human $\mathrm{T}$ helper cell apoptosis is the basic mechanism of ultraviolet-A radiation phototherapy. $J$ Exp Med 1997; 186: 1763-1768.

20 Foote CS, Wexler S, Ando S, Higgins R. Chemistry of singlet oxygen. IV. Oxygenations with hypochlorite-hydrogen peroxide. J Am Chem Soc 1968; 90: 975-981.

21 Held AM, Halko DJ, Hurst JK. Mechanisms of chlorine oxidation of hydrogen peroxide. J Am Chem Soc 1978; 100: 5732-5740.

22 Kato Y, Ogino Y, Aoki T, Uchida K, Kawakishi S, Osawa T. Phenolic antioxidants prevent peroxynitrite-derived collagen modification in vitro. J Agric Food Chem 1997; 45: 3004-3009.

23 Kanofsky JR. Quenching of singlet oxygen by human plasma. Photochem Photobiol 1990; 51: 299-303.

24 Sueishi Y, Hori M, Ishikawa M, et al. Scavenging rate constants of hydrophilic antioxidants against multiple reactive oxygen species. $J$ Clin Biochem Nutr 2014; 54: 67-74.

25 Di Mascio, Bechara EJ, Medeiros MH, Briviba K, Sies H. Singlet molecular oxygen production in the reaction of peroxynitrite with hydrogen peroxide. FEBS Lett 1994; 355: 287-289.

26 Di Mascio, Briviba K, Bechara EJ, Medeiros MH, Sies H. Reaction of peroxynitrite and hydrogen peroxide to produce singlet molecular oxygen $\left({ }^{1} \Delta_{\mathrm{g}}\right)$. Methods Enzymol 1996; 269: 395-400.

27 Adam W, Kazakov DV, Kazakov VP. Singlet-oxygen chemiluminescence in peroxide reactions. Chem Rev 2005; 105: 3371-3387.

28 Niu QJ, and Mendenhall. Yields of singlet molecular oxygen from peroxyl radical termination. J Am Chem Soc 1992; 114: 165-172.

29 Kanofsky JR. Singlet oxygen production from the reactions of alkylperoxy radicals. Evidence from 1268-nm chemiluminescence. J Org Chem 1986; 51: 3386-3388.

30 Hayashi N, Togawa K, Yanagisawa M, Hosogi J, Mimura D, Yamamoto Y. Effect of sunlight exposure and aging on skin surface lipids and urate. Exp Dermatol 2003; 12 Suppl 2: 13-17. 